\title{
Placental Malaria: Histological Findings and Immune Cell Infiltrates in Submicroscopic Infections
}

Olga María Agudelo-Garcia ( $\square$ momag204@gmail.com )

Universidad de Antioquia https://orcid.org/0000-0001-6634-3231

Eliana María Arango

Universidad de Antioquia

Stephanie K Yanow

University of Alberta

Jaime Carmona-Fonseca

Universidad de Antioquia

\section{Research}

Keywords: Plasmodium, placenta, histopathology, submicroscopic infections, immune cells, Colombia

Posted Date: March 4th, 2021

DOI: https://doi.org/10.21203/rs.3.rs-270681/v1

License: (9) This work is licensed under a Creative Commons Attribution 4.0 International License. Read Full License 


\section{Abstract}

Most research on placental malaria is focused on microscopic infection by Plasmodium falciparum; there are very few studies on submicroscopic infection. This study aimed to assess alterations of placental tissue associated with placental malaria, to describe the immune cell populations in the placental tissue, and to explore the relationships between the histopathological changes and cell infiltrates. A descriptive, prospective and cross-sectional study was carried out. Women were recruited at hospital obstetric facilities in three municipalities in Northwest Colombia. The histopathological analysis was performed in a total of 132 placentas including 66 placentas with submicroscopic plasmodial infection and 66 that were negatives. Immunohistochemistry was performed on a subset of 75 placentas to determine the distribution of immune cells. Based on histology, there were more immune cells in placentas with submicroscopic plasmodial infection compared with those without infection. The quantity of syncytial knots and calcifications was greater with submicroscopic plasmodial infection, but the quantity of abruption and thrombi was greater in placentas without infection. By immunohistochemistry, we observed a significant increase of CD56+ and CD68+ cells in the infected placentas. Submicroscopic plasmodial infection in the placenta causes tissue alterations and increased immune cell infiltrates. Submicroscopic plasmodial infection is very common in Colombia and can represent a serious threat to mothers and newborns.

\section{Background}

Malaria in pregnancy is a significant cause of maternal and infant morbidity. [1-8] When parasites infect the placenta it is known as placental malaria (PM). [9] Most studies have focused on PM diagnosed by thick blood smear (microscopic infection), but submicroscopic infections also cause PM and have pathological consequences for the mother and the fetus. [8, 10-12] In addition, most of the pathology associated with malaria in pregnancy has been observed in Plasmodium falciparum infections, but malaria in pregnancy caused by Plasmodium vivax can also lead to adverse obstetric outcomes. $[8,13$, 14]

The objectives of this study were: 1 ) to describe the placental histological changes detected in placental submicroscopic plasmodial infections; and 2) to describe the type, quantity and location of immune cell populations in the placental tissue.

The invasion of the endometrium by the trophoblast is a highly controlled process, and that control largely depends on maternal immune cells and their secreted products within the decidual microenvironment. Decidual leukocytes play an important role in this process; they increase in number during the secretory intermediate phase near the time of implantation, and they continue increasing during early pregnancy. [15] There are four main leukocyte populations in the placenta: T cells, decidual natural killer cells, placental macrophages or Hofbauer cell, and dendritic cells. Of the total decidual leukocytes, $70 \%$ are decidual natural killer cells, $20-25 \%$ are Hofbauer cell, and $1.7 \%$ are dendritic cells. 
[16] A decreased number of Hofbauer cell, decidual natural killer cells, and dendritic cells have deleterious effects on placental development and on decidual implantation or formation. [15-18]

PM is associated with a number of changes in the placental tissue that are observed by histopathology. $[5,7,8,13,14,19-21]$. Inflammatory cell infiltration in the intervillous space (IVS) is frequently observed during an active placental malarial infection, primarily from mononuclear cells, which cause inflammation in the IVS as well as in the villi. [22-24].

In pregnant women, cell-mediated immunity is modulated to promote the development of the placenta and its implantation in the maternal endometrium. But this halt in cell-mediated immunity makes pregnant women more susceptible to intracellular pathogens [25]. However, in malaria-infected pregnant women, an increase in cell-mediated immunity has been observed in the local placental environment with elevated levels of pro-inflammatory cytokines, such as IFN-y, IL-2, and TNF-a [25-27]. These cytokine levels correlate with increased Hofbauer cell density, parasite density, and malaria pigments in the placenta. Maternal macrophages are the predominant source of chemokines in the placenta, but fetal cells can also contribute. The chemokines help to recruit macrophages, cytotoxic $T$ cells, $B$ cells, and granulocytes in the placenta and contribute to the pathologies of placental malaria. There is excessive sequestration of parasitized red blood cells and leukocytes in the IVS of placenta and formation of perivillous fibrin clots during malarial infection, which interfere with blood flow across the placenta thus restricting nutrients to the fetus $[25,28,29]$.

Submicroscopic infections are common in pregnant women [30]. Submicroscopic infections can be considered chronic because they are not treated, and the persistence of antigenic stimuli can generate changes in cytokine environments and normal cell populations in peripheral and placental maternal blood $[12,31]$. In Colombia, an area of low transmission of both $P$. falciparum and $P$. vivax, there is a high frequency of submicroscopic gestational and placental infections, $49 \%$ and $57 \%$, respectively [11]. The impact of submicroscopic infections of both species in pregnancy in this area is being explored, and it has been shown that submicroscopic infection during pregnancy is frequent and can affect the health of women and their offspring [32-35].

\section{Methods}

The objective of this study was to describe the placental histological changes detected in placental submicroscopic plasmodial infections.

\section{Study location}

Women were recruited during 2009-2014 at the hospital obstetric facilities in the municipalities of Monteria $\left(08^{\circ} 45^{\prime} \mathrm{N}, 75^{\circ} 53^{\prime} \mathrm{W}\right)$, Puerto Libertador $\left(07^{\circ} 53^{\prime} 35^{\prime \prime} \mathrm{N}, 75^{\circ} 40^{\prime} 16^{\prime \prime} \mathrm{W}\right)$ and Tierralta $\left(8^{\circ} 10^{\prime} 22^{\prime \prime} \mathrm{N}\right.$ $76^{\circ} 03^{\prime} 34^{\prime \prime} 0$ ) in the Cordoba department, located in the malaria region of Colombia termed Uraba-SinuSan Jorge-Bajo Cauca region. This region is homogeneous in terms of ecoepidemiology and malaria transmission. Transmission intensity is low and stable, with no marked fluctuations in the number of 
malaria cases during the year. This region has an estimated area of $43,506 \mathrm{~km}^{2}$, malaria at-risk population of 2.5 million with a mean annual parasite index of 35.8 cases/1000 inhabitants. Most municipalities in the region are highly endemic for malaria all year. [36] The city of Monteria, the capital of the department of Córdoba, has no malaria transmission; however, due to administrative reasons, some pregnant women residing in Puerto Libertador and Tierralta are referred to Monteria for labor and delivery care.

In the study area, the antenatal care program is free, attended by trained nursing staff, and the appointments are monthly or biweekly after 36 weeks of gestation. At each antenatal care appointment, a thick blood smear (TBS) is taken from the pregnant woman, and she is febrile, the patient is referred to the malaria center for microscopic diagnosis and malaria treatment if necessary. The standard treatment is chloroquine for $P$. vivax malaria and artemether-lumefantrine for $P$. falciparum malaria.

\section{Sample design and size}

A descriptive, prospective and transversal design was used [37]. The sample was selected for convenience.

The women studied here participated in different studies, all of which included the examination of the blood of the women and placentas at the time of delivery using TBS and qPCR, as well as obtaining samples of placental tissue and clinical and epidemiological information. The goal was to obtain at least 50 placentas with Plasmodium submicroscopic placental infection (presence of the parasite detected with qPCR but negative with thick film) and 50 placentas without infection. When this quantity of samples was obtained, the objectives corresponding to what was published in this report were defined.

A total of 136 women and their placentas were included initially, 66 women negative for plasmodial infection during pregnancy and at delivery in both peripheral blood and placental blood (all tests were negatives) and 70 women with placental plasmodial infection. Of the 70 placentas positive by qPCR, four were also positive by TBS, and they were excluded from this study to focus exclusively on submicroscopic placental infection. P. falciparum was detected in $54 \%(36 / 66)$ and P. vivax in $46 \%$ $(30 / 66)$ of infected placentas.

The placental histopathological study was performed on all placentas, while the immunohistochemistry assays were carried out on a subgroup of 75 placentas: 50 qPCR positives for Plasmodium in placental blood, and 25 qPCR negatives.

\section{Inclusion and exclusion criteria}

Inclusion criteria were voluntary acceptance to participate in the study; permanent residency in the malaria endemic region ( $>1$ year); negative history of preeclampsia, gestational diabetes, arterial hypertension; and negative HIV and TORCH tests. The exclusion criterion was withdrawal of consent.

\section{Data and specimen collection}


After inclusion, a clinical-epidemiological questionnaire was completed; in addition, the clinical chart of each woman was consulted. Peripheral maternal blood was taken for the microscopic and molecular diagnosis of gestational malaria. From the placenta, after cleaning with saline, samples of tissue and blood were taken for the diagnosis of PM and the histological and immunohistochemical analysis. For the histological study, two tissue samples were taken, one close to the umbilical cord insertion or the other between the cord insertion and the edge of the placenta. A slide was made from each tissue sample and stained with hematoxylin eosin.

\section{Malaria diagnosis}

Plasmodial infection was diagnosed by TBS, quantitative real-time PCR (qPCR) and placental tissue histology. Submicroscopic infection was defined as a positive result by qPCR and a negative result by TBS and histology. TBS were read by an experienced microscopist. TBS were defined as negative if 200 fields (100X magnification) were free of parasites [38].

For molecular diagnosis, a hole punch circle $(\sim 6 \mathrm{~mm})$ from each dried blood spot was used for DNA extraction using the saponin-Chelex method. [39] The GPCR was based on a published method with some modifications. [40] Briefly, the samples were first tested for Plasmodium using genus specific primers and a hydrolysis probe (Plasprobe) on the ABI 7500 FAST platform, samples with a cycle threshold $<45$ were considered positive for plasmodial infection. The sensitivity of the qPCR assay for the detection of parasite DNA in clinical samples is limited by the input volume in the qPCR reaction, which corresponds to $\sim 2.5 \mu \mathrm{L}$ whole blood. Samples considered positive for plasmodial infection were tested in two single species-specific reactions for $P$. falciparum and $P$. vivax, performed using reverse primers specific for each species of plasmodium and combined with the conserved, forward primer, and species-specific probes.

Histological diagnosis was carried out by completely reading the microscopic slides of placental tissue stained with hematoxylin-eosin; the slides were examined by light microscopy under 100X (magnification $=1,000$; high- power field) objective lenses. Tissues presenting only parasitized red blood cells (acute $\mathrm{PM}$ ), or parasitized red blood cells with hemozoin (HZ) (chronic PM) were considered positives. Observing only $\mathrm{HZ}$ in placental tissue indicates past infection and not active. [41].

A placenta was considered positive for PM when one or more of the PM diagnostic tests (qPCR, TBS, and histology) had a positive result. Submicroscopic infection was considered when both TBS and histology were negative and qPCR was positive. A placenta was considered negative for PM when all three diagnostic tests were negative.

\section{Histopathology study}

All placental biopsy specimens were prepared and examined by one of the authors of this report (OMAG), who was supervised by a professional pathologist. Analyses were done without prior knowledge of the maternal characteristics, pregnancy outcomes, or malaria episodes in pregnancy. Details were described 
in other reports. $[5,8,11,35]$ Histological slides were examined by light microscopy under 40X (magnification $=400$ ) objective lenses.

Histological variables/events were evaluated quantitatively. This evaluation was done in two ways: a) for these events: abruption, atherosis, necrosis in the decidua, villous edema, villous infarction, hemorrhage in IVS, and thrombus in IVS, the fields with presence of the event were added, and this sum was considered as the amount of each event; b) for these events: fibrin deposits, syncytial knots, chorionic villi, fetal capillaries, capillaries per villa, calcifications in IVS, and immune cells, each event was numerated in each field, and that number was considered as the amount of the event.

Changes or lesions in the placenta were grouped into three broad categories: 1) placental vascular processes (maternal or fetal vascular stromal lesions); 2) inflammatory-immune processes (infectious inflammatory lesions; inflammatory immune / idiopathic lesions); 3) other processes [42]. The variables evaluated were defined considering recent criteria on placental histopathology in general [42-44] and we also included previous criteria on histopathology of placental malaria $[5,6,13,21,45-53]$. These definitions are listed in Table 1. 


\section{Abruptio}

Placental abruption hemorrhage; there is accumulation of blood under the decidua and dissection of it. Abruptio represents the rupture of incompletely remodeled spiral arteries due to ischemiareperfusion or atherosis. When the abruption represents the rupture of maternal veins, usually at the periphery of the placenta, this refers to marginal abruption [42].

\section{Atherosis}

Change in the spiral arteries of the decidua, specifically the thickening of the arterial endothelium. The arterioles of the placental bed show signs of fibrinoid necrosis and foam cells. These alterations are placental atherosis and are similar to the changes seen in the vessels of patients with atherosclerosis $[70,71]$.

\section{Decidual necrosis}

Ischemic area with degenerative lesions in the decidua. In decidual necrosis due to infections (malaria, toxoplasmosis, listeriosis, mycoplasmosis, virosis, etc.), focal areas of necrosis with intense infiltration with neutrophils, thrombi inside decisive blood vessels and intense bleeding are common. $[45,46]$.

\section{Villous edema}

Abnormal accumulation of fluid in the stroma of the capillaries of villi, characterized by the expansion or swelling of them and the presence of voids in the stroma. "The accumulation of fluid in the chorionic villus stroma is a poorly elucidated entity. During the second half of pregnancy there are $13 \%$ placentas with hairy edema" $[72,73]$.

\section{Chorionic villus infarction}

Ischemic necrosis of an organ (tissue death due to lack of blood and subsequently oxygen), usually due to obstruction of the arteries that supply it [43]. Gestational arterial hypertension links the placenta with increased development of infarctions and lower organ weight $[73,74]$.

\section{Fibrinoid/fibrinous deposit or fibrin deposit}

Accumulation of fibrin in the stroma of the capillaries of villi or around the capillaries of villi (in the IVS) [43]. The IVS that separate the villi from each other are very variable and can be occupied by an eosinophilic material called fibrinoid [73].

\section{Syncytial nodules}

From the second trimester of pregnancy, syncytiotrophoblast cells begin to cluster in compact nests on the surface of the capillaries of villi, leaving spaces devoid of syncytium; those cell clusters are syncytial nodes [75]. The presence of syncytial nodes has a positive correlation with the time and severity of pregnancy hypertension, as well as the presence of fibrin in the capillaries of villi [76]. Exposure to hypoxia and hyperoxia or reactive oxygen species induces the formation of syncytial nodes [45, 77-79]; these phenomena are common in malaria. In term placentas, the prevalence of syncytial nodes in capillaries of villi greater than $33 \%$ should be considered increased $[73,80]$. 


\section{Abruptio \\ Placental abruption hemorrhage; there is accumulation of blood under the decidua and dissection of it. Abruptio represents the rupture of incompletely remodeled spiral arteries due to ischemia- reperfusion or atherosis. When the abruption represents the rupture of maternal veins, usually at the periphery of the placenta, this refers to marginal abruption [42].}

\section{Chorionic villi}

The chorion is the fetal membrane that is in direct contact with the endometrium of the uterus and that covers the chorionic sac. It is formed by syncytiotrophoblast, cytotrophoblast and extraembryonic mesoderm. Capillaries of villi are cytotrophoblast cells that proliferate on the outer surface of the chorionic sac forming cellular clusters that project to the syncytiotrophoblast, and occur at the end of the second week [45]. The various kinds of capillaries of villi differ in caliber, stromal structure, morphology and blood vessel number $[73,81]$. The approximate constitution of the term placenta is $40-50 \%$ of terminal villi, $25 \%$ mature intermediate, $20-25 \%$ trunk villi, $5-10 \%$ immature intermediate and less than $1 \%$ mesenchymal villi [79]. The number of villi seen per highpowered field is significantly increased both in active and treated malaria cases compared to nonmalaria controls; there is a significant decrease in villous area in active malaria-infected cases compared to both controls and treated malaria cases [58].

\section{Capillaries}

The mesoderm cells in the center of the tertiary capillaries of villi begin to differentiate into small caliber capillaries that form arteriovenous capillary networks that constitute the tertiary capillaries of villi. At the end of the third week, blood begins to circulate through the capillaries of the capillaries of villi [45].

\section{Capillaries per chorionic villus (villous vascularity)}

The capillary network of the distal capillaries of villi serves to supply fetal blood after several generations of branching of the vessels that extend from the umbilical cord. The lesions to the integrity of the placental capillary network, which occur in different situations, have consequences that present serious risks to the health of the fetus, the infant and the adult $[47,58,82,83]$.

\section{Hemorrhage in the IVS}

Blood flow from the circulatory system, caused by the rupture of blood vessels. In this work, attention was focused on hemorrhages evaluated microscopically, which correspond to "small vessel rupture (fetomaternal hemorrhage)" [42]. "When histology confirms that the bleeding is enclosed by an infarction, the term hematoma should be used" [43].

\section{Thrombus in the IVS}

Blood clot as a result of bleeding [73].

\section{Calcifications in the IVS}

Deposition of calcium salts in the tissue[73, 84].

\section{Immune cells}

Total cells in each zone (decidua, villus and intercellular space). Immune cells have nuclei that are deeply or densely stained (chromatin is large and bulky) and almost fill the cells, with only a slight edge of cytoplasm around the nuclei. This cell can have a nucleus divided into two to five round or ovoid lobes that are connected with thin chains or small chromatin bands. Events associated with immune cells are those of villitis and intervillitis, whose definition or diagnostic criteria are currently highly problematic $[15,18,24]$. 
In formalin-fixed, paraffin embedded tissues, the EnVision system (Dako) with anti-Human CD4 (Clone 4B12, Dako), anti-Human CD8 (Clone C8/144B, Dako), anti-Human CD14 (Clone TÜK4, Dako), anti-Human CD56 (Clone 123C3), and anti-Human CD68 (Clone PG-M1, Dako) was used and each marker was used on different tissue sections. Briefly, the paraffin sections were deparaffinized and rehydrated in xylene and graded alcohols. After blocking with peroxidase in ChemMate peroxidase-blocking solution (Dako), the slides were incubated with the primary antibodies. After application of the peroxidase-labeled polymer, the slides were incubated with the diaminobenzidine substrate chromogen solution, counterstained with hematoxylin, washed again, dehydrated, and mounted. The immunohistochemical slides were observed using a Zeiss Axio Imager M2 light microscope equipped with a Zeiss Axio Cam HRc Camera to capture images of the placenta. Ten photos were collected per slide, with a 40X objective lens. Subsequently, each photograph was analyzed and the number of cells counted for each photo. The number of positive cells was calculated and analyzed using the Image J software (Image J 1.46r Wayne Rasband National Institutes of Health, USA, https://imagej.nih.gov/ij/index.html).

\section{Statistical analyses}

Most of our data were not normally distributed, based on the Kolmogorov-Smirnov test; thus, the nonparametric Mann-Whitney U-test was performed to evaluate differences between the groups. IBM SPSS Statistics (version 24) was used. Comparisons were made between the uninfected placentas group versus the infected placentas group. Significance was accepted for all analyses at $P<0.05$. Spearman's rho was used to measure the correlation between the variables.

\section{Results}

A total of 132 women and their placentas were evaluated, $50 \%(n=66)$ with submicroscopic placental plasmodial infection, $50 \%$ without infection. P. falciparum was detected in $54 \%(36 / 66)$ and $P$. vivax in $46 \%(30 / 66)$ of infected placentas. No statistically significant differences were observed between the study groups in terms of the general characteristics of women (Table 2). However, two clinically important differences were noted: the median hemoglobin level was $1 \mathrm{~g} / \mathrm{dL}$ lower in the PM group and the median birthweight was $225 \mathrm{~g}$ lower in PM. 
Table 2

General characteristics of the pregnant women

\begin{tabular}{|c|c|c|c|c|c|}
\hline \multirow[t]{5}{*}{ Variable } & \multicolumn{4}{|c|}{ Placental malaria (PM) } & \multirow{5}{*}{$\mathrm{p}(\mathrm{M}-$} \\
\hline & \multirow{2}{*}{\multicolumn{2}{|c|}{$\begin{array}{l}\text { Without PM } \\
(n=66)\end{array}$}} & \multirow{2}{*}{\multicolumn{2}{|c|}{$\begin{array}{l}\text { With PM } \\
(n=66)\end{array}$}} & \\
\hline & & & & & \\
\hline & Median & IQR & Median & IQR & \\
\hline & & $25-75 \%$ & & $\begin{array}{l}25- \\
75 \%\end{array}$ & \\
\hline Age (years) & 22 & $19-24$ & 24 & $19-29$ & 0.426 \\
\hline Gestational age at delivery (weeks) & 38 & $37-40$ & 39 & $38-40$ & 0.215 \\
\hline Hemoglobin at delivery $(\mathrm{g} / \mathrm{dL})$ & 11,67 & $11-12$ & 10,83 & $10-12$ & 0.073 \\
\hline Birth weight (g) & 3100 & $\begin{array}{l}2900- \\
3400\end{array}$ & 2875 & $\begin{array}{l}2600- \\
3000\end{array}$ & 0.281 \\
\hline $\begin{array}{l}\text { Residence time in malarious zone: }>5 \\
\text { continuous years }\end{array}$ & $93 \%$ & & $91 \%$ & & - \\
\hline \multicolumn{6}{|l|}{ Parity (previous pregnancies): } \\
\hline None (in first pregnancy) & \multicolumn{2}{|l|}{$31 \%$} & \multicolumn{2}{|l|}{$35 \%$} & - \\
\hline One (in 2nd pregnancy) & \multicolumn{2}{|l|}{$23 \%$} & \multicolumn{2}{|l|}{$19 \%$} & \\
\hline Two (in 3rd pregnancy) & \multicolumn{2}{|l|}{$15 \%$} & \multicolumn{2}{|l|}{$19 \%$} & \\
\hline With history of malaria in current pregnancy & \multicolumn{2}{|l|}{$25 \%$} & \multicolumn{2}{|l|}{$26 \%$} & - \\
\hline
\end{tabular}

\section{Histopathological findings}

Some examples of the histopathological findings detected in the infected placentas are presented in Fig. 1. The number of immune cells in the decidua, villi and IVS, as well as the number of syncytial knots and calcifications were significantly higher in infected than in uninfected placentas (Table 3). Necrosis in the decidua was detected exclusively in the presence of PM. Calcifications were abundant in infected placentas but almost absent in the uninfected group. The number of villi and capillaries per villus were reduced in placentas with PM compared with negative placentas. In contrast, edema and abruption were significantly more frequent in uninfected placentas. All histopathological findings were observed in placentas infected by $P$. vivax or $P$. falciparum. 
Table 3

Histopathological findings in placentas with and without PM

\begin{tabular}{|c|c|c|c|c|c|}
\hline \multirow[t]{5}{*}{ Variable } & \multicolumn{4}{|c|}{ Placental malaria (PM) } & \multirow[t]{5}{*}{$p(M-W)$ * } \\
\hline & \multirow{2}{*}{\multicolumn{2}{|c|}{$\begin{array}{l}\text { Without PM } \\
(n=66)\end{array}$}} & \multirow{2}{*}{\multicolumn{2}{|c|}{$\begin{array}{l}\text { With PM } \\
(n=66)\end{array}$}} & \\
\hline & & & & & \\
\hline & Median & IQR & Median & IQR & \\
\hline & & $25-75 \%$ & & $25-75 \%$ & \\
\hline \multicolumn{6}{|l|}{ Decidua } \\
\hline Atherosis & 1 & $0-2$ & 0 & $0-1$ & 0.226 \\
\hline Necrosis & 0 & $0-0$ & 0 & $0-0$ & 0.804 \\
\hline Abruption & 1 & $0-4$ & 0 & $0-3$ & 0.042 \\
\hline Immune cells & 0 & $0-3$ & 50 & $35-93$ & 0.001 \\
\hline \multicolumn{6}{|l|}{ Villus } \\
\hline Infarction & 6 & $1-16$ & 9 & $1-20$ & 0.341 \\
\hline Edema & 7 & $1-17$ & 5 & $1-12$ & 0.029 \\
\hline Syncytial knots & 86 & $67-119$ & 121 & $79-159$ & 0.023 \\
\hline Fibrin deposits & 70 & $54-84$ & 70 & $57-93$ & 0.764 \\
\hline Villus & 358 & $304-403$ & 346 & $290-380$ & 0.442 \\
\hline Capillaries by villi & 8 & $6-9$ & 8 & $5-9$ & 0.589 \\
\hline Immune cells & 20 & $9-30$ & 35 & $24-51$ & 0.039 \\
\hline \multicolumn{6}{|l|}{ IVS } \\
\hline Hemorrhage & 18 & $9-22$ & 11 & $5-18$ & 0.639 \\
\hline Thrombus & 1 & $0-2$ & 0 & $0-1$ & 0.838 \\
\hline Calcifications & 2 & $0-3$ & 3 & $0-30$ & 0.027 \\
\hline Immune cells & 65 & $40-78$ & 118 & $82-173$ & 0.001 \\
\hline
\end{tabular}

In general, the histopathological studies consider the presence of infected erythrocytes and HZ to classify PM as an acute, chronic or past infection. [51] According to that classification, the 16 cases of submicroscopic PM detected by histopathology were all past infections. The amount of HZ ranged 
between 6 to 25 deposits. In the majority of the placentas $(70 \%, 11 / 16)$, the $\mathrm{HZ}$ was free or phagocytized both in the IVS and in the villus. As expected, no HZ was detected in the villus or IVS in placentas that were qPCR negative.

\section{Immune cell populations in the placenta}

All immune cell populations increased in the presence of PM (Table 4, with representative images in Fig. 2), but the greatest increases were for CD68 + cells, followed by CD $14+$ and CD $56+$ cells, and finally CD4 + and CD $8+$ cells. Specifically, the increase in cell populations in infected tissue compared to healthy tissue were $98 \%$ for CD68+, $78 \%$ for CD $14+, 34 \%$ for CD $4+, 31 \%$ for CD $56+$, and $27 \%$ for CD $8+$. CD $56+$ cells, CD4+, and CD8 + were always observed in the decidua and IVS, while CD68 + cells were also found within the villous stroma in some cases of PM. The staining used for the immunohistochemical study limited the specific determination of the area (decidua, IVS and villi) where the cells were quantified; therefore, the location of the identified cells is indicated in a qualitative way.

Table 4

Immune cells in placental tissue

\begin{tabular}{|c|c|c|c|c|c|}
\hline \multirow[t]{5}{*}{ Variable } & \multicolumn{4}{|c|}{ Placental malaria (PM) } & \multirow[t]{5}{*}{$P(M-W)$ * } \\
\hline & \multirow{2}{*}{\multicolumn{2}{|c|}{$\begin{array}{l}\text { Without PM } \\
(n=25)\end{array}$}} & \multirow{2}{*}{\multicolumn{2}{|c|}{$\begin{array}{l}\text { With PM } \\
(n=50)\end{array}$}} & \\
\hline & & & & & \\
\hline & Median & IQR & Median & IQR & \\
\hline & & $25-75 \%$ & & $25-75 \%$ & \\
\hline CD4 + Cells & 11 & $10-12$ & 15 & $14-16$ & 0.0001 \\
\hline CD8 + Cells & 10 & $9-11$ & 13 & $11-15$ & \\
\hline CD14 + Cells & 32 & $28-34$ & 53 & $51-57$ & \\
\hline CD56 + Cells & 78 & $74-80$ & 98 & $94-110$ & \\
\hline CD68 + Cells & 43 & $30-53$ & 91 & $74-98$ & \\
\hline
\end{tabular}

\section{Significant bivariate linear correlations between histological events and immune cells}

Correlation is a statistical technique used to determine the relationship between two or more quantitative variables and indicates (i) the strength of the association; (ii) the direction or meaning of the association; (iii) the shape of the association (indicates the type of line that defines the best fit: straight line, monotonic curve or non-monotonic curve). To analyze the relationship between variables, the "correlation coefficients" were used. The existence of correlation does not imply cause-effect relationships. To explore 
the relationship between histological events, between immune cell populations, and between events and cells, a simple linear correlation analysis was performed.

Uninfected placentas: 25 significant bivariate linear correlations between histological events and immune cells were found, of which $4(20 \%)$ had $p<0.05$ and the rest (80\%) $p<0.01$ (Fig. 3). Immune cell infiltrates in decidua correlated with immune cell infiltrates in villi, and the latter correlated with immune cell infiltrates in the IVS.

Infected placentas: 24 significant bivariate linear correlations were found between histological events and immune cells, of which $6(26 \%)$ had $p<0.05$ and $74 \%$ had $p<0.01$ (Fig. 3). Immune cell infiltrates in the IVS correlated with immune infiltrates in decidua and villi, but these two variables did not correlate with each other.

As can be deduced from Fig. 3, the amount and class of correlations identified between histological events has little variation between the two groups.

\section{Discussion}

An important achievement of this study was to describe the histological alterations that are frequent in placentas with submicroscopic infections. There are reports that do not show associations between submicroscopic infections and negative pregnancy outcomes [10,32,54-56], but there are also reports that submicroscopic infection during pregnancy affects the health of the mother and the fetus [10-12, $32,55,57-59]$. These infections in maternal peripheral blood or in the placenta may cause pathological effects on maternal and infant health, although, apparently, with lesser magnitude than microscopic infections. Considerations of other variables such as the frequency, density, and timing of parasitemia of gestational malaria are also important risk factors for PM. [60]

Here we showed the effects of submicroscopic infection on histopathological changes associated with inflammatory processes, consistent with our previous studies. $[5,11]$ The placentas with submicroscopic infection had more immune cells and more tissue changes or alterations than the uninfected placentas, except for atherosis, abruption, edema, hemorrhage, and thrombus. These findings confirm the pathogenic nature of the parasite in this organ.

PM is manifested by important changes in placental architecture, such as the presence of inflammatory cell infiltrates, as well as for the release of proinflammatory mediators in the IVS, fibrin deposits, cytotrophoblast cell proliferation, necrosis, and thickening of the trophoblastic basal membrane. $[2,13$, 21] In addition, infected erythrocytes, and free or phagocytosed $\mathrm{HZ}$ deposits have been observed. [48] In our study, we found similar alterations suggesting that inflammation is generated by the infection leading to the accumulation of proinflammatory immune cells in the decidua and in the IVS. In particular, we noted an increase in NK cells, which could generate a proinflammatory and modulating environment at the expense of the activity of these cells to increase the migration of other cells and the elimination of the parasite. In $P$. falciparum infection, NK cells are known to mediate an important host response as these 
cells produce IFN-y and TNF that contribute to suppress the infection or to develop complications [61]. We also observed a predominance of CD68 + cells, consistent with the proinflammatory environment. These cells respond to the infection by phagocytosing infected erythrocytes and the products of the parasite ( $\mathrm{HZ}$ and microvesicles). In turn, the increased infiltrate of macrophages and infected erythrocytes, inflammatory reactions, and intervillitis may reduce the exchange of nutrients and oxygen through the placenta, reducing the availability of oxygen to the fetus, and resulting in placental hypoxia and intrauterine growth restriction. [7, 42, 62-64]

The observed increase in immune cells could be explained as a consequence of the production of microvesicles from circulating infected erythrocytes, which come from the maternal and placental circulation. In murine models and in cell cultures, these microvesicles have powerful immunomodulatory activity on monocytes, macrophages, and neutrophils. [65] HZ can also have an immunostimulatory effect on the syncytiotrophoblast, mediated by chemokines that facilitate the recruitment of peripheral blood mononuclear cells to the placenta. $[66,67]$

We further explored correlations between different parameters of PM to advance our understanding of the histological changes and the physiological processes that occur during PM. The results of bivariate linear correlations indicated that immune cell infiltrates are the central points of correlation to the histological changes, in both infected and uninfected placentas, while the different cells identified by immunohistochemistry did not participate in interactions with histological events, except CD 4 + cells. These correlated events are, essentially, the same in the absence or in the presence of infection.

\section{Conclusions}

These results demonstrate that the diagnosis of PM by histology lacks sensitivity to detect submicroscopic infection and the frequency of PM in this region is likely to be underestimated. Additionally, it is evident that submicroscopic infection in the placenta generates important changes in its morphology that can affect the development of pregnancy $[13,52,68,69]$. These findings may affect intervention strategies to reduce the burden of PM in Colombia and in other parts of the Americas, where a microscopic diagnosis of plasmodial infection is essential to administer adequate treatment and avoid complications associated with gestational malaria.

\section{Abbreviations}

CD: cluster of differentiation. Ct: cycle threshold. DNA: deoxyribonucleic acid. EDTA: ethylenediaminetetraacetic acid. IVS: intervillous space. PM: placental malaria. qPCR: quantitative realtime polymerase chain reaction. TBS: thick blood smear. TORCH: acronym is used universally to refer to a fetus or newborn presenting clinical features compatible with a vertically acquired infection and allows a rational diagnostic and therapeutic approach. The microorganisms classically included are Toxoplasma gondii, rubella virus, cytomegalovirus, herpes simplex virus and other agents. SPI: submicroscopic plasmodial infection. 


\section{Declarations}

\section{Ethics approval and consent to participate}

The study protocol was reviewed and approved by: a) Ethics Committee of the Sede de Investigaciones Universitarias SIU, Universidad de Antioquia (Medellín, Colombia) (act number 07-32-126: project code 111540820495, contract: 238-2007, Colciencias); b) Ethics Committee of the Instituto de Investigaciones Médicas, Universidad de Antioquia (act number 12: project code 111549326134, contract 611-2009, Colciencias). Each participant gave full informed consent according to the Helsinki convention and the Colombian regulations for this type of research. Each subject voluntarily agreed to participate in the study.

\section{Consent for publication}

Not applicable

\section{Availability of data and materials}

Not applicable

\section{Competing interests}

The authors declare that they have no conflicts of interest.

\section{Funding}

This work was supported by the Departamento Administrativo de Ciencia, Tecnología e Innovación Colciencias (project codes 111574454975, 111577757051). The Universidad de Antioquia (Estrategia Sostenibilidad 2016-2017)

\section{Authors' contributions}

OMAG, JC-F and EAF conceived the project and designed the experiments, supervised overall design and development and wrote the manuscript. SKY edited the manuscript.

\section{Acknowledgements}

The authors are grateful to the participating patients, field assistants, employees and managers of the local hospitals for their collaboration.

\section{References}

1. Desai M, ter Kuile FO, Nosten F, McGready R, Asamoa K, Brabin B, Newman RD: Epidemiology and burden of malaria in pregnancy. Lancet Infect Dis 2007, 7:93-104. 
2. Rogerson SJ, Hviid L, Duffy PE, Leke RF, Taylor DW: Malaria in pregnancy: pathogenesis and immunity. Lancet Infect Dis 2007, 7:105-117.

3. Malhotra I, McKibben M, Mungai P, McKibben E, Wang X, Sutherland LJ, Muchiri EM, King CH, King $C L$, LaBeaud AD: Effect of antenatal parasitic infections on anti-vaccine IgG levels in children: a prospective birth cohort study in Kenya. PLoS Neg/ Trop Dis 2015, 9:e0003466.

4. Mandala WL, Msefula CL, Gondwe EN, Drayson MT, Molyneux ME, MacLennan CA: Monocyte activation and cytokine production in Malawian children presenting with P. falciparum malaria. Parasite Immuno/ 2016, 38:317-325.

5. Carmona-Fonseca J, Arango E, Maestre A: Placental malaria in Colombia: histopathologic findings in Plasmodium vivax and P. falciparum infections. Am J Trop Med Hyg 2013, 88:1093-1101.

6. Ahenkorah J, Tetteh-Quarcoo PB, Nuamah MA, Kwansa-Bentum B, Nuamah HG, Hottor B, Korankye E, Torto M, Ntumy M, Addai FK: The impact of Plasmodium infection on placental histomorphology: a stereological preliminary study. Infect Dis Obstet Gynecol 2019, 2019:2094560.

7. Ahmed R, Singh N, ter Kuile FO, Bharti PK, Singh PP, Desai M, Udhayakumar V, Terlouw DJ: Placental infections with histologically confirmed Plasmodium falciparum are associated with adverse birth outcomes in India: a cross-sectional study. Malar J 2014, 13:232.

8. Lopez-Guzman C, Carmona-Fonseca J: Malaria placentaria submicroscópica: histopatología y expresión de mediadores de procesos fisiológicos. Rev Peru Med Exp Salud Publica 2020, 37:220.

9. Lamikanra OT: A study of malaria parasitaemia in pregnant women, placentae, cord blood and newborn babies in Lagos, Nigeria. West Afr J Med 1993, 12:213-217.

10. Arango E, Maestre A, Carmona-Fonseca J: [Effect of submicroscopic or polyclonal Plasmodium falciparum infection on mother and gestation product: systematic review]. Rev Bras Epidemiol 2010, 13:373-386.

11. Arango EM, Samuel R, Agudelo OM, Carmona-Fonseca J, Maestre A, Yanow SK: Molecular detection of malaria at delivery reveals a high frequency of submicroscopic infections and associated placental damage in pregnant women from northwest Colombia. Am J Trop Med Hyg 2013, 89:178183.

12. Agudelo O, Aristizabal B, Yanow S, Arango E, Carmona-Fonseca J, Maestre A: Submicroscopic infection of placenta by Plasmodium produces Th1/Th2 cytokine imbalance, inflammation and hypoxia in women from north-west Colombia. Malar J 2014, 13:122.

13. McGready R, Davison BB, Stepniewska K, Cho T, Shee H, Brockman A, Udomsangpetch R, Looareesuwan S, White NJ, Meshnick SR, Nosten F: The effects of Plasmodium falciparum and P. vivax infections on placental histopathology in an area of low malaria transmission. Am J Trop Med Hyg 2004, 70:398-407.

14. Mayor A, Bardají A, Felger I, King CL, Cisteró P, Dobaño C, Stanisic DI, Siba P, Wahlgren M, del Portillo $\mathrm{H}$, et al: Placental infection with Plasmodium vivax: a histopathological and molecular study. $\mathrm{J}$ Infect Dis 2012, 206:1904-1910.

15. Bulmer JN, Williams PJ, Lash GE: Immune cells in the placental bed. Int J Dev Bio/ 2010, 54:281-294. 
16. Mor G, Cardenas I: The immune system in pregnancy: a unique complexity. Am J Reprod Immunol 2010, 63:425-433.

17. Mor G, Cardenas I, Abrahams V, Guller S: Inflammation and pregnancy: the role of the immune system at the implantation site. Ann N Y Acad Sci 2011, 1221:80-87.

18. Sanguansermsri D, Pongcharoen S: Pregnancy immunology: decidual immune cells. Asian Pac J Allergy Immunol 2008, 26:171-181.

19. Parekh FK, Davison BB, Gamboa D, Hernandez J, Branch OH: Placental histopathologic changes associated with subclinical malaria infection and its impact on the fetal environment. Am J Trop Med Hyg 2010, 83:973-980.

20. Ordi J, Bardají A, Castillo P, Ismail MR, Menéndez C: Grading schemes for placental malaria. J Infect Dis 2011, 203:1694-1695; author reply 1695-1696.

21. Ismail MR, Ordi J, Menendez C, Ventura PJ, Aponte JJ, Kahigwa E, Hirt R, Cardesa A, Alonso PL: Placental pathology in malaria: a histological, immunohistochemical, and quantitative study. Hum Pathol 2000, 31:85-93.

22. Ordi J, Menendez C, Ismail MR, Ventura PJ, Palacín A, Kahigwa E, Ferrer B, Cardesa A, Alonso PL: Placental malaria is associated with cell-mediated inflammatory responses with selective absence of natural killer cells. J Infect Dis 2001, 183:1100-1107.

23. Chaisavaneeyakorn S, Lucchi N, Abramowsky C, Othoro C, Chaiyaroj SC, Shi YP, Nahlen BL, Peterson DS, Moore JM, Udhayakumar V: Immunohistological characterization of macrophage migration inhibitory factor expression in Plasmodium falciparum-infected placentas. Infect Immun 2005, 73:3287-3293.

24. Ortega-Pajares A, Rogerson SJ: The Rough Guide to Monocytes in Malaria Infection. Front Immunol 2018, 9:2888.

25. Ribeiro IM, Souto PCS, Borbely AU, Tanabe ELL, Cadavid A, Alvarez AM, Bueno J, Agudelo O, Robles RG, Ayala-Ramírez $P$, et al: The limited knowledge of placental damage due to neglected infections: ongoing problems in Latin America. Syst Biol Reprod Med 2020, 66:151-169.

26. Maestre A, Carmona-Fonseca J: Immune responses during gestational malaria: a review of the current knowledge and future trend of research. J Infect Dev Ctries 2014, 8:391-402.

27. Davison BB, Kaack MB, Rogers LB, Rasmussen KK, Rasmussen TA, Henson EW, Henson MC, Parekh FK, Krogstad DJ: The role of soluble tumor necrosis factor receptor types I and II and tumor necrosis factor-alpha in malaria during pregnancy. $J$ Infect Dis 2006, 194:123-132.

28. Conroy A, Serghides L, Finney C, Owino SO, Kumar S, Gowda DC, Liles WC, Moore JM, Kain KC: C5a enhances dysregulated inflammatory and angiogenic responses to malaria in vitro: potential implications for placental malaria. PLoS One 2009, 4:e4953.

29. Miu J, Mitchell AJ, Müller M, Carter SL, Manders PM, McQuillan JA, Saunders BM, Ball HJ, Lu B, Campbell IL, Hunt NH: Chemokine gene expression during fatal murine cerebral malaria and protection due to CXCR3 deficiency. J Immuno/ 2008, 180:1217-1230. 
30. Khan WA, Galagan SR, Prue CS, Khyang J, Ahmed S, Ram M, Alam MS, Haq MZ, Akter J, Glass G, et al: Asymptomatic Plasmodium falciparum malaria in pregnant women in the Chittagong Hill Districts of Bangladesh. PLoS One 2014, 9:e98442.

31. Ibitokou SA, Boström S, Brutus L, Tuikue Ndam N, Vianou B, Agbowaï C, Amadoudji Zin M, Huynh BT, Massougbodji A, Deloron P, et al: Submicroscopic infections with Plasmodium falciparum during pregnancy and their association with circulating cytokine, chemokine, and cellular profiles. Clin Vaccine Immunol 2014, 21:859-866.

32. Álvarez-Larrotta C, Agudelo OM, Duque Y, Gavina K, Yanow SK, Maestre A, Carmona-Fonseca J, Arango E: Submicroscopic Plasmodium infection during pregnancy is associated with reduced antibody levels to tetanus toxoid. Clin Exp Immunol 2019, 195:96-108.

33. Gavina K, Gnidehou S, Arango E, Hamel-Martineau C, Mitran C, Agudelo O, Lopez C, Karidio A, Banman S, Carmona-Fonseca J, et al: Clinical Outcomes of Submicroscopic Infections and Correlates of Protection of VAR2CSA Antibodies in a Longitudinal Study of Pregnant Women in Colombia. Infect Immun 2018, 86.

34. Carmona-Fonseca J, Agudelo OM, Arango EM: Asymptomatic plasmodial infection in Colombian pregnant women. Acta Trop 2017, 172:97-101.

35. Agudelo-García OM, Arango-Flórez EM, Carmona-Fonseca J: Submicroscopic and Asymptomatic Congenital Infection by Plasmodium vivax or P. falciparum in Colombia: 37 Cases with Placental Histopathology and Cytokine Profile in Maternal and Placental Blood. J Trop Med 2017, 2017:3680758.

36. Carmona-Fonseca J: La Región “Urabá Antioqueño-Cuencas altas de los ríos Sinú y San Jorge-Bajo Cauca Antioqueño": "guarida" del paludismo colombiano. Rev Univ Ind Santander Salud 2017 49(4):577-589

37. Colimon K-M: Fundamentos de epidemiología. 1 edn. España1990.

38. López-Antuñano, F., Schmunis G: Diagnosis of Malaria. In Microscopic diagnosis of malarial parasites in the blood. Washintong: Pan American Health Organization; 1990: 37-47

39. Plowe CV, Djimde A, Bouare M, Doumbo O, Wellems TE: Pyrimethamine and proguanil resistanceconferring mutations in Plasmodium falciparum dihydrofolate reductase: polymerase chain reaction methods for surveillance in Africa. Am J Trop Med Hyg 1995, 52:565-568.

40. Shokoples SE, Ndao M, Kowalewska-Grochowska K, Yanow SK: Multiplexed real-time PCR assay for discrimination of Plasmodium species with improved sensitivity for mixed infections. J Clin Microbiol 2009, 47:975-980.

41. Galbraith RM, Faulk WP, Galbraith GM, Holbrook TW, Bray RS: The human materno-foetal relationship in malaria: I. Identification of pigment and parasites in the placenta. Trans R Soc Trop Med Hyg 1980, 74:52-60.

42. Redline RW: Classification of placental lesions. Am J Obstet Gynecol 2015, 213:S21-28.

43. Khong TY, Mooney EE, Ariel I, Balmus NC, Boyd TK, Brundler MA, Derricott H, Evans MJ, FayePetersen OM, Gillan JE, et al: Sampling and Definitions of Placental Lesions: Amsterdam Placental 
Workshop Group Consensus Statement. Arch Pathol Lab Med 2016, 140:698-713.

44. Aplin JD, Beristain A, DaSilva-Arnold S, Dunk C, Duzyj C, Golos TG, Kemmerling U, Knöfler M, Mitchell MD, Olson DM, et al: IFPA meeting 2016 workshop report III: Decidua-trophoblast interactions; trophoblast implantation and invasion; immunology at the maternal-fetal interface; placental inflammation. Placenta 2017, 60 Suppl 1:S15-S19.

45. Botella Llusiá J: La placenta. Fisiología y patología. 1 edn. Madrid1992.

46. Baergen R: Manual of Pathology of the Human Placenta. 2nd edition edn. New York2011.

47. Chaikitgosiyakul S, Rijken MJ, Muehlenbachs A, Lee SJ, Chaisri U, Viriyavejakul P, Turner GD, Pongponratn E, Nosten F, McGready R: A morphometric and histological study of placental malaria shows significant changes to villous architecture in both Plasmodium falciparum and Plasmodium vivax infection. Malar J 2014, 13:4.

48. Muehlenbachs A, Fried M, McGready R, Harrington WE, Mutabingwa TK, Nosten F, Duffy PE: A novel histological grading scheme for placental malaria applied in areas of high and low malaria transmission. J Infect Dis 2010, 202:1608-1616.

49. Souza RM, Ataíde R, Dombrowski JG, Ippólito V, Aitken EH, Valle SN, Álvarez JM, Epiphanio S, Epiphânio S, Marinho CR: Placental histopathological changes associated with Plasmodium vivax infection during pregnancy. PLoS Negl Trop Dis 2013, 7:e2071.

50. Hromatka BS, Ngeleza S, Adibi JJ, Niles RK, Tshefu AK, Fisher SJ: Histopathologies, immunolocalization, and a glycan binding screen provide insights into Plasmodium falciparum interactions with the human placenta. Biol Reprod 2013, 88:154.

51. Bulmer JN, Rasheed FN, Francis N, Morrison L, Greenwood BM: Placental malaria. I. Pathological classification. Histopathology 1993, 22:211-218.

52. Walter PR, Garin Y, Blot P: Placental pathologic changes in malaria. A histologic and ultrastructural study. Am J Pathol 1982, 109:330-342.

53. Galbraith RM, Fox H, Hsi B, Galbraith GM, Bray RS, Faulk WP: The human materno-foetal relationship in malaria. II. Histological, ultrastructural and immunopathological studies of the placenta. Trans $R$ Soc Trop Med Hyg 1980, 74:61-72.

54. Doritchamou JYA, Akuffo RA, Moussiliou A, Luty AJF, Massougbodji A, Deloron P, Tuikue Ndam NG: Submicroscopic placental infection by non-falciparum Plasmodium spp. PLoS Neg/ Trop Dis 2018, 12:e0006279.

55. Saute F, Menendez C, Mayor A, Aponte J, Gomez-Olive X, Dgedge M, Alonso P: Malaria in pregnancy in rural Mozambique: the role of parity, submicroscopic and multiple Plasmodium falciparum infections. Trop Med Int Health 2002, 7:19-28.

56. Cottrell G, Moussiliou A, Luty AJ, Cot M, Fievet N, Massougbodji A, Deloron P, Tuikue Ndam N: Submicroscopic Plasmodium falciparum Infections Are Associated With Maternal Anemia, Premature Births, and Low Birth Weight. Clin Infect Dis 2015, 60:1481-1488.

57. Mockenhaupt FP, Rong B, Till H, Eggelte TA, Beck S, Gyasi-Sarpong C, Thompson WN, Bienzle U: Submicroscopic Plasmodium falciparum infections in pregnancy in Ghana. Trop Med Int Health 
2000, 5:167-173.

58. Cohee LM, Kalilani-Phiri L, Boudova S, Joshi S, Mukadam R, Seydel KB, Mawindo P, Thesing P, Kamiza S, Makwakwa K, et al: Submicroscopic malaria infection during pregnancy and the impact of intermittent preventive treatment. Malar J 2014, 13:274.

59. Mohammed AH, Salih MM, Elhassan EM, Mohmmed AA, Elzaki SE, El-Sayed BB, Adam I:

Submicroscopic Plasmodium falciparum malaria and low birth weight in an area of unstable malaria transmission in Central Sudan. Malar J 2013, 12:172.

60. Briggs J, Ategeka J, Kajubi R, Ochieng T, Kakuru A, Ssemanda C, Wasswa R, Jagannathan P, Greenhouse B, Rodriguez-Barraquer I, et al: Impact of Microscopic and Submicroscopic Parasitemia During Pregnancy on Placental Malaria in a High-Transmission Setting in Uganda. J Infect Dis 2019, 220:457-466.

61. Agudelo O, Bueno J, Villa A, Maestre A: High IFN-gamma and TNF production by peripheral NK cells of Colombian patients with different clinical presentation of Plasmodium falciparum. Malar J 2012, $11: 38$.

62. Boeuf P, Tan A, Romagosa C, Radford J, Mwapasa V, Molyneux ME, Meshnick SR, Hunt NH, Rogerson SJ: Placental hypoxia during placental malaria. J Infect Dis 2008, 197:757-765.

63. Sarr D, Aldebert D, Marrama L, Frealle E, Gaye A, Brahim HO, Niang M, Dangou JM, MercereauPuijalon O, Lehesran JY, Jambou R: Chronic infection during placental malaria is associated with upregulation of cycloxygenase-2. Malar J 2010, 9:45.

64. Ataíde R, Murillo O, Dombrowski JG, Souza RM, Lima FA, Lima GF, Hristov AD, Valle SC, Di Santi SM, Epiphanio S, Marinho CR: Malaria in Pregnancy Interacts with and Alters the Angiogenic Profiles of the Placenta. PLoS Negl Trop Dis 2015, 9:e0003824.

65. Mantel PY, Hoang AN, Goldowitz I, Potashnikova D, Hamza B, Vorobjev I, Ghiran I, Toner M, Irimia D, Ivanov AR, et al: Malaria-infected erythrocyte-derived microvesicles mediate cellular communication within the parasite population and with the host immune system. Cell Host Microbe 2013, 13:521534.

66. Lucchi NW, Sarr D, Owino SO, Mwalimu SM, Peterson DS, Moore JM: Natural hemozoin stimulates syncytiotrophoblast to secrete chemokines and recruit peripheral blood mononuclear cells. Placenta 2011, 32:579-585.

67. Olivier M, Van Den Ham K, Shio MT, Kassa FA, Fougeray S: Malarial pigment hemozoin and the innate inflammatory response. Front Immunol 2014, 5:25.

68. Ordi J, Ismail MR, Ventura PJ, Kahigwa E, Hirt R, Cardesa A, Alonso PL, Menendez C: Massive chronic intervillositis of the placenta associated with malaria infection. Am J Surg Pathol 1998, 22:10061011.

69. Ismaili J, van der Sande M, Holland MJ, Sambou I, Keita S, Allsopp C, Ota MO, McAdam KP, Pinder M: Plasmodium falciparum infection of the placenta affects newborn immune responses. Clin Exp Immunol 2003, 133:414-421. 
70. Staff AC, Dechend R, Pijnenborg R: Learning from the placenta: acute atherosis and vascular remodeling in preeclampsia-novel aspects for atherosclerosis and future cardiovascular health. Hypertension 2010, 56:1026-1034.

71. Reyna-Villasmil E, Santos-Bolívar J, Suárez-Torres I: Microparticles in pregnancy and preeclampsia. Rev Obstet Ginecol Venezuela 2013, 73(4):268-276.

72. Castejón O, Ali S, Canache L: El edema de la vellosidad placentaria en los casos de muerte fetal. Gaceta Médica de Caracas 2006, 14.

73. Castejón-S O, López-G A, Péres Ybarra L, Castejón-M O: Presencia de alteraciones histopatológicas en vellosidades placentarias normales en Maracay (Venezuela). Revista Colombiana de Obstetricia y Ginecología 2009, 60:10.

74. Prieto-Gómez R, Ottone N, Sandoval-Vásquez C, Saavedra A, Bianchi H: Morphoquantitative Characteristics of Free Corial Vellosities in Normal Births, with Diabetes, Hypertension and Restriction of Intrauterine Growth. Int J Morphol 2018:551-556

75. Coleman SJ, Gerza L, Jones CJ, Sibley CP, Aplin JD, Heazell AE: Syncytial nuclear aggregates in normal placenta show increased nuclear condensation, but apoptosis and cytoskeletal redistribution are uncommon. Placenta 2013, 34:449-455.

76. Corrêa RR, Gilio DB, Cavellani CL, Paschoini MC, Oliveira FA, Peres LC, Reis MA, Teixeira VP, Castro EC: Placental morphometrical and histopathology changes in the different clinical presentations of hypertensive syndromes in pregnancy. Arch Gynecol Obstet 2008, 277:201-206.

77. Heazell AE, Moll SJ, Jones CJ, Baker PN, Crocker IP: Formation of syncytial knots is increased by hyperoxia, hypoxia and reactive oxygen species. Placenta 2007, 28 Suppl A:S33-40.

78. Scifres CM, Nelson DM: Intrauterine growth restriction, human placental development and trophoblast cell death. J Physio/ 2009, 587:3453-3458.

79. Apaza-Valencia J: Desarrollo placentario temprano: aspectos fisiopatológicos. Rev peru ginecol obstet 2014, 60.

80. Loukeris K, Sela R, Baergen RN: Syncytial knots as a reflection of placental maturity: reference values for 20 to 40 weeks' gestational age. Pediatr Dev Pathol 2010, 13:305-309.

81. Isaza-Mejía G, Yepes-Zapata G, Castaño M: Arquitectura histológica de la placenta humana al contraste de fases y aplicaciones clínicas. Rev Col Obst y Ginec 1971, 22.

82. Merz G, Schwenk V, Shah R, Salafia C, Necaise P, Joyce M, Villani T, Johnson M, Crider N: Threedimensional Rendering and Analysis of Immunolabeled, Clarified Human Placental Villous Vascular Networks. J Vis Exp 2018.

83. Prieto-Gómez R, Matamala F, Rojas M: Características morfológicas y morfométricas de la placenta de término, en recién nacidos pequeños para la edad gestacional (PEG) en la ciudad de TemucoChile. Int J Morpho/ 2008, 26:615-621.

84. Castejón O, Belouche R, Morett V: El proceso de calcificación en la placenta humana. Gac méd Caracas 1998, 106(4):496-501. 


\section{Figures}
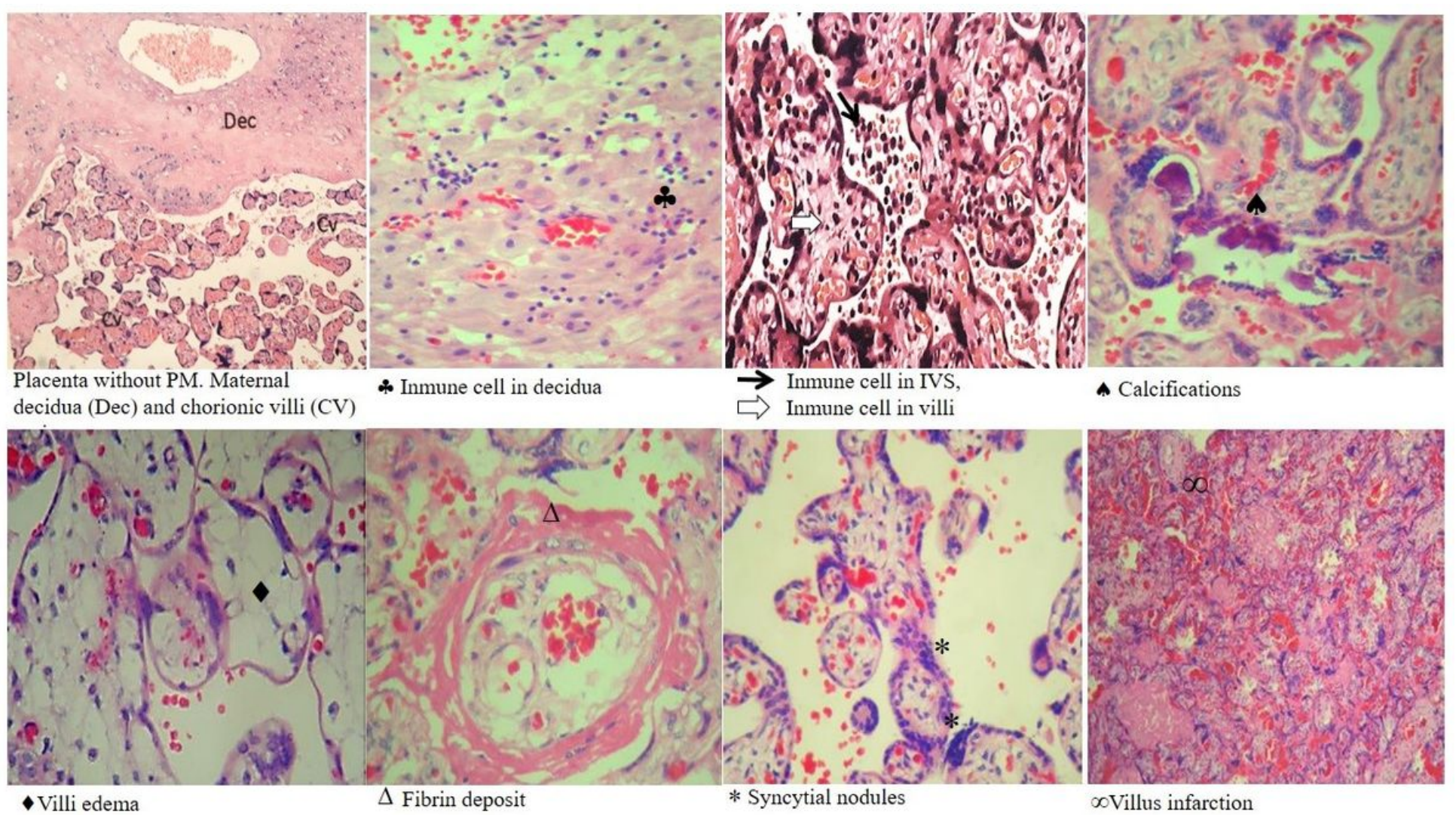

\section{Figure 1}

Histological analyses of placental tissue with PM. Placental tissue was stained with H \& E. (100X). 

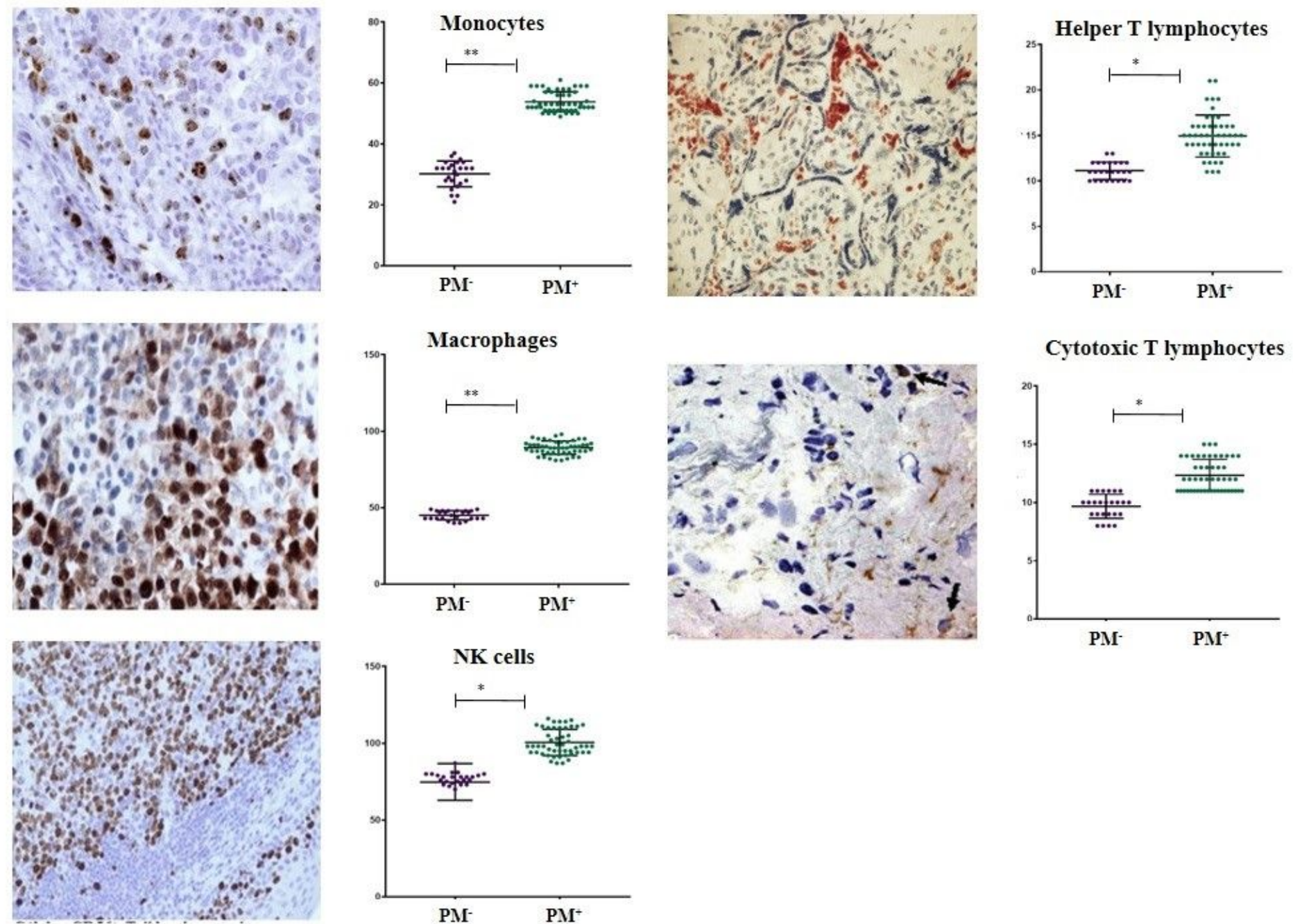

\section{Cytotoxic T lymphocytes}

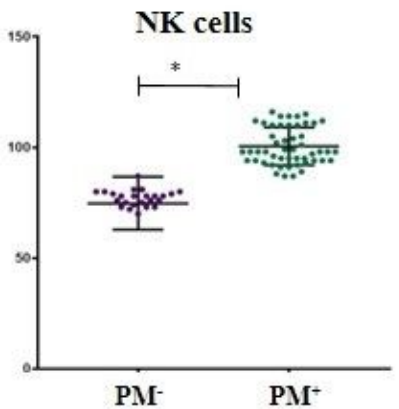

\section{Figure 2}

Immunohistochemistry for cell surface molecules in placental tissue, with and without PM. Tissues were labeled with peroxidase and positive cells are darkened. Hematoxylin was used as a contrast stain. A. CD14+ cell (Monocytes) B. CD68+ (Macrophages) C. CD56+ (Decidual NK cells) D. CD4+ cell (Helper T lymphocytes) E. CD8+ cells (Cytotoxic T lymphocytes) Statistically significant difference between the groups with PM and without PM (Mann-Whitney test for two groups) $p<0.01$ (**) 


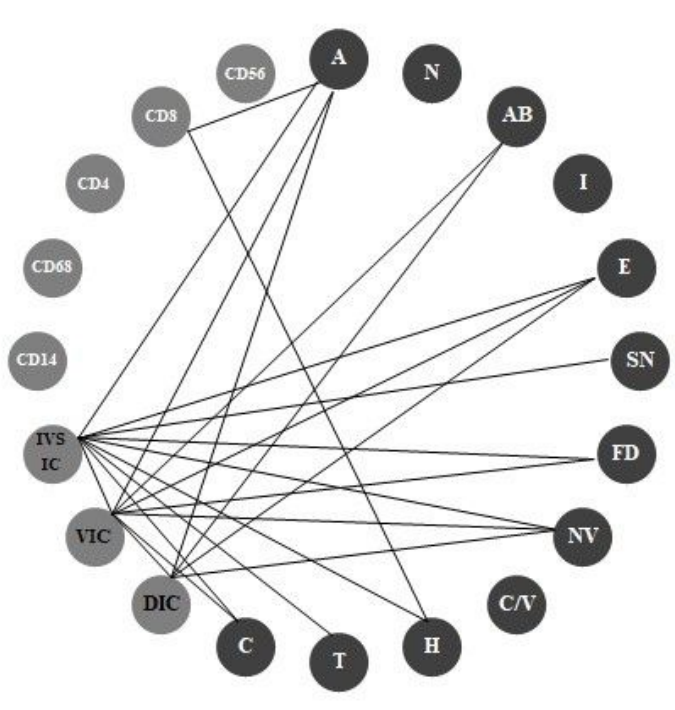

Without PM

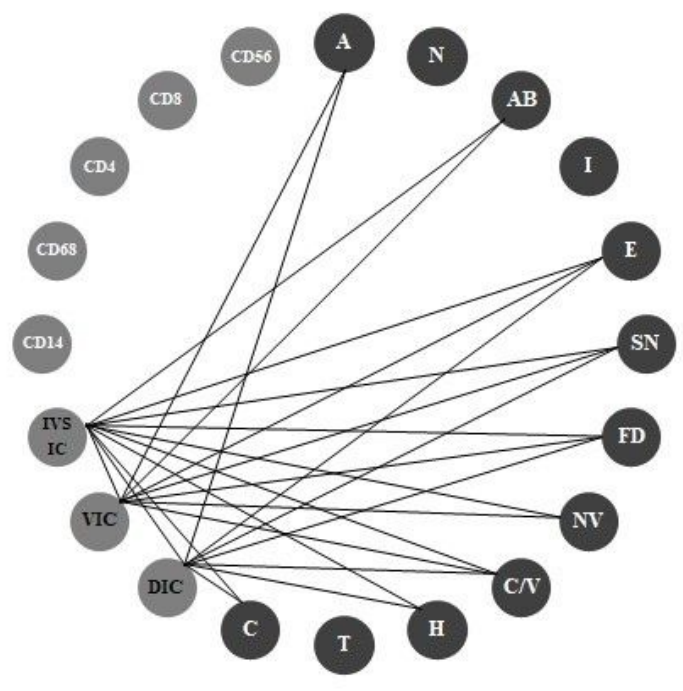

With PM

\begin{tabular}{|ll|}
\hline Decidua & \\
\hline Aterosis & A \\
Necrosis & N \\
Abruption & AB \\
Immune cells & DIC \\
\hline Villus & \\
\hline Infarction & I \\
Edema & E \\
Syncytial nodes & SN \\
Fibrin deposits & FD \\
Villus & NV \\
Capillaries by villi & C/V \\
Immune cells & VIC \\
\hline Intervillous space & \\
\hline Hemorrhage & H \\
Thrombus & T \\
Calcifications & C \\
Immune cells & IVSIC \\
\hline Immune cells & \\
\hline Monocytes & CD14 \\
Macrophages & CD68 \\
Helper T lymphocytes & CD4 \\
Cytotoxic T lymphocytes & CD8 \\
NK cells & CD56 \\
\hline
\end{tabular}

\section{Figure 3}

Significant bivariate linear correlations between histological events and immune cell populations. Correlations in the group without PM (left), and in the group with PM (right). Correlations are included with $p<0.05$ and $p<0.01$. 